\title{
Who benefits from flood management policies?
}

N. Walmsley, E. Penning-Rowsell, J. Chatterton \& K. Hardy

Reproduced from:

Flood Risk Management - Research and Practice Proceedings of FLOODrisk 2008

Keble College, Oxford, UK

30 September to 2 October 2008 


\title{
Who benefits from flood management policies?
}

\author{
N. Walmsley \\ HR Wallingford Ltd., Wallingford, Oxfordshire, UK \\ E. Penning-Rowsell \\ Flood Hazard Research Centre, Enfield Middlesex, UK
}

J. Chatterton

John Chatterton \& Associates, Birmingham, UK

K. Hardy

Defra, London, UK

Large parts of England are at risk of flooding from rivers and the sea. Areas particularly at risk include the Humber corridor, the coastal areas in the South and East, low lying areas in East Anglia and the South West and major estuaries. Some 2.1 million properties are estimated to be in flood risk areas, affecting 4.3 million people ( 8.7 per cent of the population) and of these, around 469,000 properties are at significant risk of flooding (affecting 900,000 people).

Defra has policy responsibility for flood and coastal erosion risk management (FCERM) in England and the over-arching policy is to reduce risks to people, property and the environment from flooding and coastal erosion through the provision of defences, flood forecasting and warning systems, increased flood resilience of property, beneficial land management changes and discouragement of inappropriate development in areas at risk of flooding. Managing flood risk therefore encompasses a broad range measures but is not restricted to public intervention alone and factors such as flood insurance are also important within a risk management context.

FCERM measures provide a complex mix of public and private benefits to, and burdens on, society over long time periods. However, there is currently only limited understanding and evidence of how different interest groups and sectors benefit from public investments (or decisions not to invest) in reducing flood and coastal erosion risks. A series of case study assessments have been undertaken to provide evidence of the size and scale of benefits, costs and other intangible resource flows between different sector and interest groups. The case studies cover a broad mix of FCERM activities including the provision of defences, flood forecasting and warning, emergency response, flood resilience, spatial planning and flood insurance. The case study findings improve understanding of winners and losers, help to identify distributional imbalances, and can serve to inform future FCERM policies and programmes.

The research was commissioned as part of Theme 1: Strategy and Policy Development of the joint Defra/EA Research and Development (R\&D) programme.

Keywords: Flood risk management, Defra/EA R\&D 


\title{
Fluid thinking...smart solutions
}

HR Wallingford provides world-leading analysis, advice and support in engineering and environmental hydraulics, and in the management of water and the water environment. Created as the Hydraulics Research Station of the UK Government in 1947, the Company became a private entity in 1982, and has since operated as a independent, non profit distributing firm committed to building knowledge and solving problems, expertly and appropriately.

Today, HR Wallingford has a 50 year track record of achievement in applied research and consultancy, and a unique mix of know-how, assets and facilities, including state of the art physical modelling laboratories, a full range of computational modelling tools, and above all, expert staff with world-renowned skills and experience.

The Company has a pedigree of excellence and a tradition of innovation, which it sustains by re-investing profits from operations into programmes of strategic research and development designed to keep it - and its clients and partners - at the leading edge.

Headquartered in the UK, HR Wallingford reaches clients and partners globally through a network of offices, agents and alliances around the world.

\section{HR Wallingford}

Working with water

\author{
HR Wallingford Ltd \\ Howbery Park \\ Wallingford \\ 0xfordshire 0X10 8BA \\ UK
tel $\quad+44(0) 1491835381$
fax +44 (0)1491832233
email info@hrwallingford.co.uk

\section{www.hrwallingford.co.uk}

